\title{
研究者として成功するために 何が必要か?
}

\section{一ノーベル賞受賞者と若手の議論を通じて考えること}

中西和嘉

\section{背景}

筑波会議2019が2019年10月2日から4日の 日程でつくば国際会議場にて開催された。筑波 会議は若手で構成する「ダボス会議」を目指し ており、本会議では、[Society 5.0 とSDGsを見 据えた目指すべき社会の在り方とその実現に向 けて取り組むべき課題にに関連した様々なテー マが掲げられ、議論がなされた。その中で、2 日目に開催された「ノーベル賞受賞者を囲むス ペシャルプレナリー」は一般公開とされ、「若手 が研究者として成功するために何が必要か？」 をテーマにしてノーベル賞受賞者と若手研究者 が意見し、多くの若手研究者や学生が参加し、 質問を投げかけ、パネルデイスカッションが進 められた。登壇者は参考情報に詳細を記載した ${ }^{1}$ 。 登壇者の一人として当日の内容と議論を通じて 考えることをここに共有したい。

本セッションは、当初はノーベル賞受賞者が、 聴衆を含め、若手研究者や学生にレクチャーす るという、一般的なやり方が提示されていたが、 筑波会議の一つの特色である、「若手を中心に進 める」方法に変更された。すなわち、ノーベル 賞受賞者と若手研究者それぞれが、テーマに対 する考えをのべ、会場からの質問も含めて議論 しようという試みが若手主導でなされた。

\section{当日の議論 (ガッツvsシステム改革)}

今回、登壇者として参加した若手研究者はグ ローバルヤングアカデミー（GYA）、または若 手アカデミー、あるいはその両方に所属する。 GYAは「世界の若手科学者の声」となることを 目的とし、2010年に設立された若手科学者の 国際的なアカデミー組織である ${ }^{2,3,4}$ 。若手アカ デミーは、若手研究者の発想を社会の諸課題の 解決に活かし、将来の学術界を担う若手研究者 を育成するため、2014年に日本学術会議が設置 した若手科学者の組織である 50 。それぞれのビ ジョンや活動が新福博士、岸村博士によって紹 介された。

ディスカッションテーマを選定するにあたり、 若手研究者自身をとりまく、あるいは若手研究 者の視点から見えるいくつもの問題提起があっ た。諸問題をどのようにクリアすれば、研究者 として成功することができるか、というポジティ ブなテーマに集約できると考え、また、研究で 大きな成功を収めていることに違いないノーべ ル賞受賞者の意見を聞くには最適のテーマであ ると考え、「若手が研究者として成功するために 何が必要か?」をデイスカッションテーマとし、 岩崎博士、新福博士らがモデレーターとして議 論を進めることにした。 
まず、江崎博士が導入のための講演を行い、 過去の常識、情報に惑わされず、感性と好奇心 を失わないことなど、5つのやってはいけない 重要ポイントを紹介した。山中博士はこれら5 つのポイントに同意するとともに、現在は装置 性能や技術の向上で昔より情報が得やすいため、 研究は進めやすいと激励した。Walker博士は多 様な分野の研究者が融合できるような、環境の 重要性をあげるとともに、研究テーマ選択の重 要性、また自分が信じた道を進むことの重要性 について述べた。小林博士は人や研究の環境の 重要性などを指摘しつつ、何が大きな成功につ ながるかは分からない部分がある（セレンディ ピティー）ことも述べた（写真 1$)$ 。Stoddart博 士はクロージングセッションでスピーチし、誰 もやっていない重要なテーマを決めて、それに 熱意をもって取りかかることが重要だと述べ、 時には困難を伴うが、やると決めたらそれに向 かってまっすぐに突き進むように、と若手にエー
ルを送った（写真2）。大きくまとめると、ノー ベル賞受賞者からは、研究者としての意気込み （ガッツ）を伝えていただいた。

一方、若手研究者らは、研究で大きな成功を 収めるために必要である基盤が不足しているこ とを訴えた。つまり、意気込み（ガッッ）以外 のシステムの問題を指摘した。Vermeir博士は真 に重要な研究を行うための十分な研究時間や研 究費、研究者間の交流が重要であるとし、また、 研究の評価は量ではかるべきでないと訴え、昨 今の研究や大学、研究所の評価法に疑問を投げ かけた。Saliba博士は若いうちから成功と失敗 の両方を経験すること、また失敗を受け入れら れる環境であることの重要性を述べるとともに、 過激な競争下では失敗のリスクをとれないこと も指摘した。中西はまわりや社会でなく、自分 が重要だと考える研究テーマを行える自由度が 必要であることを訴え、現状はプロジェクト型 研究や応用志向の研究への投資が多く、テーマ

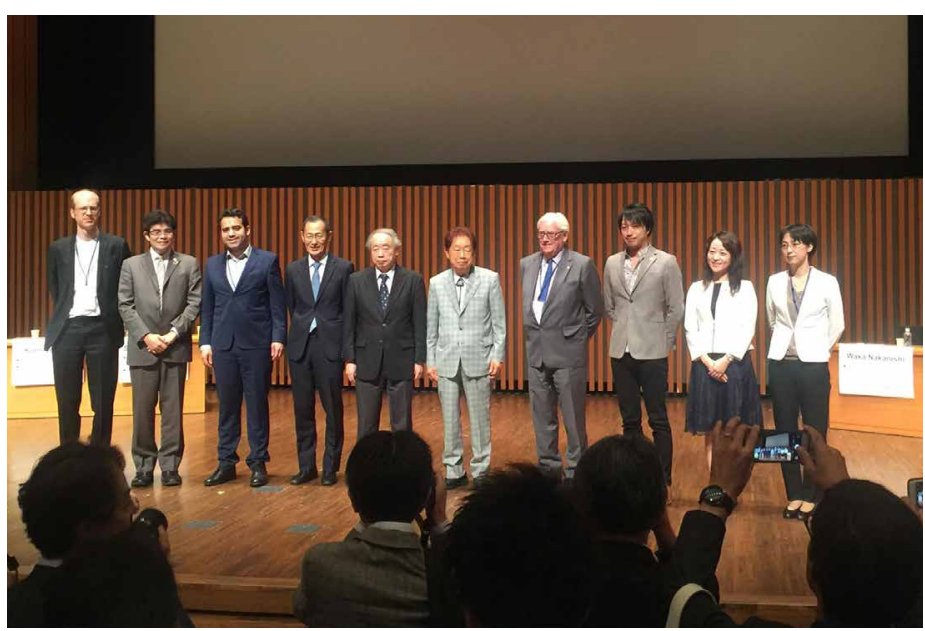

写真1 セッション後の様子。向かって左から、Vermeir博士、岸村博 士、Saliba博士、山中博士、小林博士、江崎博士、Walker博士、 岩崎博士、新福博士、中西 (筆者)。

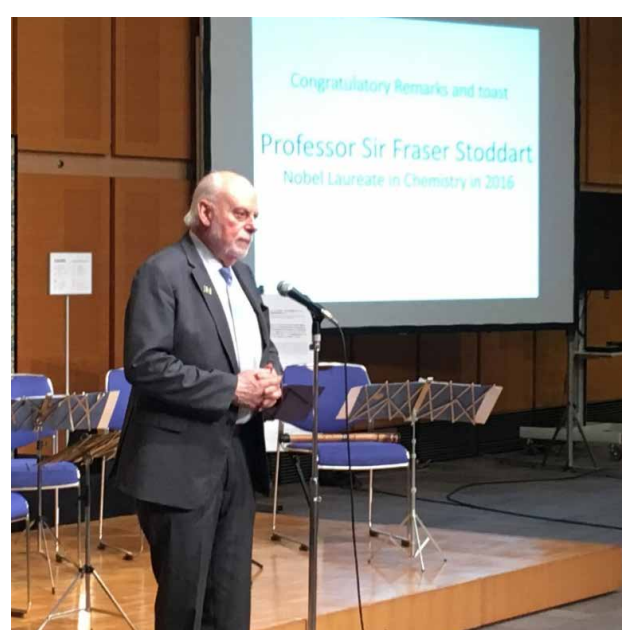

写真2 クロージングセッションにて Stoddart 博士が若手にエールを送る。 
を選べる自由が少なくなってきていることを指 摘した。

若手、ノーベル賞受賞者にかかわらず、各人 が重要だと考えるポイントは、共通する点が多 く見られた。その一方で、ノーベル賞受賞者は、 各自が挙げた重要なポイントは強い意志（ガッ ツ）をもって得る・実行すべしとエールを送っ たのに対し、若手は強い意志（ガッツ）だけで は限界があり、システムの改革が必要であると 考えたのは対照的である。

\section{考えること（社会のための研究、ただし、 より広い時空のなかで)}

今回、若手研究者もノーベル賞受賞者も、研 究に専念できる時間と予算を確保でき、各自が 考える重要で挑戦的な研究テーマに取り組むこ とが重要であるという共通認識があったことは 特筆すべきである。研究者が自由に発想して行 う研究は、筑波会議の大きな方向性（Society 5.0 とSDGsを見据えた目指すべき社会の在り方と その実現に向けて取り組むべき課題）に逆行す るようだが、そうではない。

前日の基調講演で、小林喜光氏（三菱ヶミカ ルホールディングス取締役会長) がアカデミア に重要なことの一つに百科事典であること、と 述べた。多様な研究の中で、その時代の要求に 対応できる英知が蓄積されているかが重要であ ることが産業界からも述べられたことの意義は 大きい。つまり、多様な研究を行うこと、あるテー マに集中しすぎないことは、産業、社会にも役
に立つといえる。ここでは科学者の独善でなく て、科学、産業、社会が信頼した関係を築くこ とが重要だとされた。

より長いスパン、広い目で見れば、基礎研究 を含め、多様な研究が社会の役に立つという産 業界からの意見は心強い。一方、信頼関係を築 くための努力は、産業界に対しても社会に対し ても益々必要になると感じた。若手アカデミー では分野の垣根を超えた、あるいは研究者の枠 組みを超えたワークショップや会議開催等によ り、信頼関係を築くための活動を模索し実行し ている。

\section{日本の置かれた状況と今後に向けて (自ら動く)}

多くの分析や、ノーベル賞受賞者らもが日本 の研究環境に危機感を発信しており、20年後は ノーベル賞級の研究成果が出てくることはなく なると警鐘を鳴らしている $7,8,9$ 。現在、研究以 外のサービスへの従事増加、様々な事務作業の 増加、それらによる研究時間の減少、不安定で 低賃金な雇用、博士課程志望者の減少、基盤研 究費（運営費交付金）の減少、研究テーマの自 由度の減少、等々、様々な課題がある。若手ア カデミーとしては、諸問題の解決に向けた実行 力をともなう活動として、シニア研究者や行政 サイドとの適切な協働のもとで政策決定プロセ スに直接関わる努力を続けている。例えば、シ ニア委員の多い文部科学省科学技術・学術審議 会の分科会や委員会へ若手世代を代表して議論 
に参加しているほか、山極壽一議員（日本学術 会議会長）を通じて総合科学技術・イノベーショ ン会議（CSTI）へ若手の意見を届ける ${ }^{10}$ など積 極的に行動を起こしてきた。最近、CSTIから発 表された「研究力強化·若手研究者支援総合パッ ケージ」においても、このような活動の成果が 垣間見られると考えており、今後も継続してい きたい。

注

1 登壇者:

モデレーターとして、若手アカデミー幹事・岩崎渉（東京 大学大学院理学系研究科准教授、Global Young Academy x ンバー）、若手アカデミー副代表・新福洋子（京都大学大 学院医学研究科准教授、Global Young Academy執行委員) が議論をサポートした。

ノーベル賞受賞者登壇者として、江崎玲於奈博士（茨城 県科学技術振興財団理事長、1973年ノーベル物理学賞） 小林誠博士（高エネルギー加速器研究機構特別栄誉教授、 2008年ノーベル物理学賞) 山中伸弥博士（京都大学iPS細 胞研究所所長/教授、2012年ノーベル生理学・医学賞) John Ernest Walker博士 (Emeritus Director and Professor at the MRC Mitochondrial Biology Unit in Cambridge、1997年 ノーベル化学賞）が発表し、Sir James Fraser Stoddart博士 (Northwestern University、2016年ノーベル化学賞) はク ロージングセッションで本セッションに対する意見を述べ た。

若手研究者登壇者として、Koen Vermeir博士（Co-Chair, Global Young Academy, Research Professor, French National Center for Scientific Research (CNRS), Affiliate Professor at the University of Paris)、Michael Saliba博士（Executive Committee, Global Young Academy Professor, the Technical University of Darmstadt)、岸村顕広博士（九州大学大学 院工学研究院准教授、若手アカデミー代表、Global Young Academyメンバー）、中西和嘉（若手アカデミーメンバー、 物質・材料研究機構 機能性材料研究拠点主任研究員）が登 壇した。

2 Global Young AcademyのWWWサイト (https:// globalyoungacademy.net/)

3 グローバルヤングアカデミーにおけるSDGsへの取り組み, 駒井章治, 学術の動向, 2018.1, p. 68-71.

4 グローバルヤングァカデミー 第一回総会に参加して, 竹村仁 美・田中由浩, 学術の動向, 2011.10, p. 72-73.

5 若手アカデミーのwwwサイト（http://www.scj.go.jp/ja/scj/ wakate/index.html)
6 若手アカデミーの発足, 住井英二郎, 学術の動向, 2016.3, p. 118-120.

7 科学者が消える—ノーベル賞が取れなくなる日本, 岩本宣 明, 東洋経済新報社.

8 誰が科学を殺すのか一一科学技術立国「崩壊」の衝撃, 毎日 新聞「幻の科学技術立国」取材班, 毎日新聞出版.

9 科学立国の危機一一失速する日本の研究力, 豊田長康, 東洋 経済新報社.

10 科学新聞, 2019年8月30日1面. 